\title{
THE ASEAN CHARTER: AN ANALYSIS
}

Abdul Razak Ahmad, Associate Professor, Universiti Pertahanan

Nasional Malaysia, Malaysia. Email: arazaka@upnm.edu.my

Abstract: The adoption of the ASEAN Charter in 2007 was believed to have transformed ASEAN to become a more institutional organisation with a profound framework and inclusive principles that act as a guideline to assist the process of disputes settlement and decision-making between the member countries. When the Eminent Persons Group (EPG) representing each of the countries addressed two main issues related to the recommendations to reform the norm and principles of ASEAN as well as the rights of the member countries to be put into the Charter, the ASEAN leader were not very receptive with the concept of using consensus decision-making process to impose sanctions and changes. Therefore, a watereddown ASEAN Charter was adopted portraying the un-readiness of the member countries to diverge away from the 'ASEAN Way' that had been implemented for the past 40 years. Despite the addition of two new principles that touches on the collective responsibility and enhancing consultation, the ASEAN Charter still does not exhibit the transformation of ASEAN as crafted by the EPG. The Charter also fails to provide pertinent mechanisms to address certain issues such as security and safety disputes. Hence, this article is written to confer the weaknesses of the ASEAN Charter and how important it is for ASEAN to move away for the usual norm of the 'ASEAN Way' in order to become a puissant organisation.

Keywords: ASEAN Charter, EPG

\section{INTRODUCTION}

Over the last 40 years, the practices of ASEAN indicated a crisis of identity, trying on the one hand to appear as an international organisation in an international system, but on the other hand seeming to lack the legal authority to define its personality. However, in 2004, Malaysia proposed the idea of introducing an ASEAN Charter 
and the proposal was formally adopted at the Eleventh ASEAN Summit in 2005 (ASEAN, 2005). Immediately after the Summit, an Eminent Persons Group (EPG) representing each ASEAN member was appointed, and mandated to provide the ASEAN leaders with 'bold and visionary' recommendations for the Charter (ASEAN, 2005). After an extensive consultative meeting with various stakeholders including civil society and the business networks, dubbed the 'Consultations with the People', the EPG submitted their recommendations to the ASEAN Heads of Governments during the Twelfth ASEAN Summit in Cebu, Philippines in January 2007 (ASEAN, 2006).

The EPG report addressed a wide range of issues, but two very vital fundamental issues generated the most interest: first, the recommendations for reform in relation to ASEAN's principles and norms, and second, the rights and obligations of member countries. While trying to consolidate the many declared principles and norms of ASEAN articulated in several ASEAN documents, the EPG report called for "the active strengthening of democratic values, good governance, rejection of unconstitutional and undemocratic changes of government, through the respect and institutionalisation of the rule of law, including humanitarian law" (ASEAN, 2005). The report also addressed the need for ASEAN "to have the power to redress cases of serious breach of ASEAN's objectives" and the suggestions made included "suspension of any of the rights and privileges of membership" (ASEAN, 2005).

The above recommendations reflected a strong and progressive move by the EPG to encourage the ASEAN leaders to be bold in their efforts to bring about meaningful reform of ASEAN principles and its institutional infrastructure. The idea of imposing suspensions or sanctions also reflected the change in terms of approach where "sticking to the practice of 'lowest common denominator' in the standards of behaviour was no longer acceptable in a maturing ASEAN," (Anthony, 2008: 74). However, despite the optimism generated by the EPG report, ASEAN leaders were not receptive to the idea of sanctions and changes in the consensus decisionmaking process and a watered-down ASEAN Charter was formally adopted by leaders on the 20th November 2007 (Leviter, 2010: 159). 
The adoption of a watered-down version of the Charter indicated the deep division of member countries over the future direction of ASEAN (Leviter, 2010: 194 \& Burton and Landingin, 2007). ASEAN members were not ready to depart from the 'ASEAN Way' although they realised that institutional change is necessary for enhanced regional integration (Leviter, 2010: 165). As pointed out by Manalo, the Chair of the High Level Task Force mandated to draft the Charter, "there had been general tendency to create a Charter that will keep the inter-governmental character of ASEAN and dispel any suggestion of creating a supra-national body".

The Charter consists of a preamble and 13 chapters with 55 provisions altogether (ASEAN, 2007). The Preamble calls upon the ASEAN members to respect the fundamental importance of the sovereignty of countries, reaffirming the principle of noninterference and consensus, and to adhere to democratic principles, the rule of law, good governance and human rights. It also reaffirmed the commitment of ASEAN member countries in establishing a legal and institutional framework through the Charter. ASEAN also aspires to enhance regional cooperation and integration through the establishment of an ASEAN Community comprising the ASEAN Security Community, the ASEAN Economic Community and the ASEAN Socio-Cultural Community.

\section{NEW PRINCIPLES}

While the Charter has reaffirmed the ASEAN principle of respecting Member States' independence and their sovereignty and refraining from intervening in the domestic affairs of another member country, it has also introduced two new principles that could possibly reform how the non-interference principles should operate in the future. As a key ASEAN official puts it, "the non-interference principle is progressively undergoing changes and it is best reflected in Articles 2 (b) and (g) of the Charter" (ASEAN Secretariat, 2010). Article 2 (b) of the Charter introduced the principle of "shared commitment and collective responsibility in enhancing regional peace, security and prosperity" while article 2 (g) is about "enhanced consultations on matters seriously affecting the common interest of ASEAN". 
An ASEAN security official argued that "the application of the noninterference principles must be seen in the context of its application" (ASEAN Secretariat, 2010). It is a common understanding that the principle "should only be invoked when it concerns the domestic issues of Member States. When it relates to regional concerns, such as terrorism, it is not the case." (ASEAN Secretariat, 2010). The two new principles indicate that the principle is slowly being diluted with the notion of shared commitment, collective responsibility and enhanced consultations in matters that have regional consequences. As argued by the ASEAN official, "in ASEAN now, we hear less and less about non-interference. We are already changing our mindset. Our sovereignty is no more absolute because of regional commitments" (ASEAN Secretariat, 2010). This is a significant move by ASEAN and the discussion on the Thailand-Cambodia conflict over the temple of Preah Vihear in the latter part of this chapter illustrates how these two principles have been applied in the context of the ASEAN non-interference principle. However, despite the introduction of the two new principles, the new Charter did little to reflect the true transformation of ASEAN as an institution as suggested by the EPG. The Charter merely consolidates the existing principles and norms which could be found in the previous pronouncements and there seems to be no significant shift from the conventional 'ASEAN Way' (Leviter, 2010: 164).

\section{ASEAN LEGAL PERSONALITY}

Article 3 of the Charter is considered the most fundamental in the transformation of ASEAN as an international organisation. The article conferred on ASEAN a legal personality and recognises it as an inter-governmental organisation. This will allow ASEAN to have the capacity under international law to enter into relations with other international organisations or States besides empowering ASEAN with the rights to enter into a treaty. The granting of a legal personality is perhaps the most important contribution of the Charter although this is insufficient to address ASEAN's other institutional deficiencies. In relation to a membership in ASEAN, Article 6 provides that membership is based on the location in the recognised geographical region of Southeast Asia. This criterion reaffirmed the 
criteria in the Bangkok Declaration which states that ASEAN 'is open for participation to all States in the South-East Asian Region' (ASEAN, 1967) although there appears to be no other States left within the geographical region of Southeast Asia. Though Article 2 of the Charter states that ASEAN countries have committed themselves to the 'principles of democracy and constitutional government', nevertheless admission into ASEAN is not contingent on the criterion of democratic governance (Seah, 2009).

Although there have been changes to the ASEAN bureaucracy, it is only related to several 'hierarchical changes' (Desierto, 2010) and not structural adjustments that could facilitate meaningful reform of ASEAN as an institution. Article 7 says that the ASEAN Summit shall be the supreme policy-making body of ASEAN, and the Summit shall comprise of the Heads of State or Government of the member countries. The Summit meetings shall be held twice annually, and the leaders are empowered to deliberate, provide policy guidance and take decisions on key ASEAN issues including all issues referred to it by the ASEAN Coordinating Council, the ASEAN Community Councils and the ASEAN Sectoral Ministerial Bodies. The Summit is also the final arbiter, should there be a failure to reach a settlement of conflicts among member countries. The institutionalisation by changing the frequency of Summit meetings to twice annually is an indication of ASEAN's seriousness in enhancing regional cooperation. It represents a departure from ASEAN's previous practice where Summits were only held three times, in 1976, 1977 and 1987, since its establishment (Desierto, 2010).

\section{ENHANCING INSTITUTIONALIZATION}

The Charter also provides for the establishment of an ASEAN Coordinating Council, which comprises of ASEAN Foreign Ministers, and shall meet twice a year (ASEAN, 2007). The mandate of the Council includes: preparation for the ASEAN Summit, coordinating the decisions of the Summit, coordinating the ASEAN Community Councils to enhance policy coherence, efficiency and cooperation among them, and undertaking other tasks provided 
by the Charter and such other functions assigned by the ASEAN Summit (ASEAN, 2007). Article 9 relates to the establishment of the ASEAN Community Councils, which shall comprise of the ASEAN Political-Security Community Council, the ASEAN Economic Community and the ASEAN Socio-Cultural Community Council. These councils are mandated to ensure the implementation of relevant decisions by the ASEAN Summit as well as to coordinate the work of different sectors under their purview. Another vital consolidation exercise found in the Charter is the appointment of Permanent Representatives by each Member State, which are to be based in Jakarta with the rank of an ambassador (ASEAN, 2007). This provision is to strengthen each member's representation in the affairs of ASEAN and shall become a vital interface between the ASEAN Secretariat and the member countries. However the Charter failed to deliver the mechanisms to address issues, such as the failure to implement commitments and agreements, timeliness of specific initiatives and accountability. This reflects that the 'ASEAN Way' continued to be dominant in the functioning of ASEAN.

ASEAN's effort to be a strong and influential international organisation in the region is reflected in Article 13 of the Charter which requires each member to establish an ASEAN National Secretariat. Its function is to serve as a national focal point which will coordinate the implementation of ASEAN decisions at the national level besides promoting ASEAN identity and community building. Such a move is crucial in ensuring ASEAN's decisions are acted upon. The provision is also seen as not only enhancing ASEAN cooperation but rather institutionalising regulation as a primary mechanism for cooperation (Seah, 2009). But what remedy is available if a Member State ignores, suspends or fails to comply with the decisions of various aspects of ASEAN's Treaty, the Summit decisions or the international law norms adopted by the ASEAN Charter? (Desierto, 2010: 303). What is the mandate given by the ASEAN National Secretariat in cases of non-compliance of an ASEAN decision?

The Charter's strong attachment with the 'ASEAN Way' is best reflected in Article 20(1). It reaffirmed that consultation and consensus in decision-making is the 'basic principle of ASEAN'. 
Interestingly, the Charter provides that in the event where consensus cannot be reached, the ASEAN Summit will decide on how specific decisions can be made. Unfortunately the Charter did not stipulate the mechanism on which the Summit should decide, whether through voting or some other formula, though it can be argued that the Charter did not prohibit nor endorse the Summit from taking a vote. However, voting is not consistent with the 'ASEAN Way', which prefers diplomatic persuasion, and consensus-based decisionmaking.

In the implementation of economic commitments, the Charter introduced a flexible participation formula based on ASEAN Minus $\mathrm{X}$ for as long as there is a consensus to do so (ASEAN, 2007). This provision would allow those States which are economically developed and progressive to move forward with their economic commitment while the less developed States should not be an obstacle to the region's economic goals as long as there is a consensus among members in doing so. Seah argues that such an arrangement shows that ASEAN integration is 'a two-track process between the older and new members such as Vietnam, Laos and Cambodia' (Seah, 2009: 206). But such an argument fails to appreciate the dynamics of ASEAN in managing the cohesiveness of the region as a community despite the disparity in the level of economic development between Member States.

\section{COMPLIANCE AND DISPUTE SETTLEMENT}

Article 20 (4) addresses the issue of a serious breach of the Charter or non-compliance - that it shall be referred to the ASEAN Summit for decision. The lack of provision for effective compliance and accountability mechanisms may impede the effective implementation of regional agreements between the Member States. It is difficult to justify this reliance on the Summit, and it is unclear how the Summit will act decisively on issues of compliance. The Charter also did not provide the ASEAN Secretary General or the ASEAN Secretariat with the mandate to require compliance among members. Seah argues that the Member States were reluctant to empower the Secretariat 
for fear that both the Secretary General and the Secretariat could become 'a powerful body which can have its own life and influence' and this would allow it to determine the agenda for the grouping (Seah, 2009: 205). Furthermore, to empower the Summit with the 'quasi judicial' power in "matters referred to it under Chapters V11 (Decision Making) and VIII (Settlement of Disputes)" (ASEAN, 2007) is not a progressive move. The ASEAN Summit would not be the best forum for the settlement of disputes because of its nature as a forum for negotiations and consultation instead of an adjudicating body (Leviter, 2010: 199). This is not what was envisioned by the EPG which wanted an independent institution for conflict resolution.

In relation to the dispute settlement mechanism, Article 22 requires Member States to resolve all disputes peacefully through dialogue, consultation and negotiation, and ASEAN shall establish dispute settlement mechanisms in all fields of cooperation. ASEAN's decision to develop a dispute settlement mechanism is another move towards institutionalisation whereby Collier and Lowe argued, "Acceptance of a particular procedure for the settlement of disputes is regarded as an integral part of rights and duties that make up the status of membership of a particular community" (Collier and Lowe, 1999). This move is also concurrent with the view of Abbott and others that the definition of delegation in the concept of legalisation refers to the authority to "implement, interpret and apply the rules" and to resolve disputes (Abbott and other, 2000). Article 23 encourages Member State parties to the dispute to resort to good offices, conciliation and mediation in resolving their disputes within an agreed time limit. In Article 24, the Charter provides that disputes pertaining to the interpretation or application of the ASEAN economic commitments shall be settled in accordance with the ASEAN Protocol on Enhanced Dispute Settlement Mechanism. It is argued that the dispute mechanism procedures introduced in the Charter provide an avenue for a binding resolution to economic disputes and downplay the significance of consensus-based decision-making, an interesting departure from the traditional norm of the 'ASEAN Way'. However there was no mention of how other matters, including security related disputes, shall be addressed. 


\section{ASEAN AND HUMAN RIGHTS}

One of the important developments brought about by the Charter is the establishment of a human rights body whose terms of reference shall be determined by the ASEAN Foreign Ministers Meeting (ASEAN, 2007). The establishment of such a body conforms with the purposes and principles of the ASEAN Charter relating to the promotion and protection of human rights and fundamental freedoms (ASEAN, 2007). Article 14 is seen to give meaning and effect to Article 2(2)(i), which calls for respect for fundamental freedoms, the promotion and protection of human rights and the promotion of social justice by member countries. It is also to compliment Article 1(7) which provides that the purposes of ASEAN are, among others, to promote human rights and fundamental freedoms, with due regard to the rights and responsibilities of the Member States. The decision to include the human rights body in the Charter is due to what Thio argued in the 1990s to be a "sea of change" in ASEAN regarding human rights issues based on an increasing awareness among the people, the civil society movement, the Government, and international pressure over the importance of human rights and the issue of fundamental freedom (Thio, 1992).

During the 10th ASEAN Summit in Vientiane, the ASEAN Declaration against Trafficking in Persons, Particularly Women and Children was adopted (ASEAN, 2004). This move illustrated the softening of positions by ASEAN member countries on the issue of human rights and fundamental freedom. This was followed by a call by the ASEAN Heads of State during the 11th ASEAN Summit for Myanmar to expedite the transition towards democracy and to release those placed under detention by the Myanmar military junta (ASEAN, 2005). ASEAN's changing attitude towards human rights and fundamental freedom was again manifested during the 13th ASEAN Summit in Singapore when it called on Myanmar to lift restrictions on Daw Aung San Suu Kyi, release all political detainees and work towards a peaceful transition to democracy (ASEAN, 2007). The statement illustrates ASEAN's departure from its strict adherence to the rule on non-intervention into the internal affairs of a member country. This commitment by ASEAN is a manifestation of how ASEAN is now very conscious of its international standing 
as an important regional player in the Asia Pacific Region . Even though the Charter did not stipulate the mechanisms for how the human rights body should function, it is a historical move because ASEAN has gone beyond the traditional economic and trade related agenda to something more fundamental in achieving holistic socioeconomic and security aspirations. As argued by Duxbury, 'an organisation that wishes to strengthen its commitment to human rights and democracy within Member States clearly indicates a dilution in the importance of the principle of non-intervention' (Duxbury, 2007).

\section{CONCLUSION}

The coming into force of the ASEAN Charter is significant in many ways beyond formally conferring its legal personality. It is argued that the Charter will make ASEAN an organisation which operates under a rules-based system where the end result would lead to more compliance and accountability. Despite the remarkable initiative by ASEAN in adopting the Charter, though it was significantly watered down from the initial recommendation made by the EPG, it requires political will from all member countries to make it a living document which can help transform ASEAN into a stronger, united and cohesive international organisation. ASEAN member countries must be willing to accept the changes brought about by the Charter; and an ASEAN which is rules-based, with a new culture of taking obligations seriously, with a consolidated and streamlined institutional structure and a system of compliance monitoring and settlement of disputes (Seah, 2009: 114). The Charter raised expectations about ASEAN and it must now be supported by genuine and sustained political commitment.

The institutionalisation building of ASEAN is a move towards making ASIAN a highly developed organisation. This is relevant to the contention of the thesis that for ASEAN to be effective in executing its role of delivering security for the region, then serious reform must be undertaken to strengthen its institutional framework. Multilateral cooperation in areas such as counter-terrorism demands 
ASEAN to function differently, based on rules and compliance and with a new culture of taking its security obligation seriously. This is only possible with the greater institutionalisation development of ASEAN.

\section{BIBLIOGRAPHY}

Abbott, K.W., \& others. (2000). The Concept of Legalization. International Organisation, 54: 401.

Anthony, M.C. (2008). The ASEAN CHARTER - An Opportunity Missed or One that Cannot Be Missed? Southeast Asian Affairs, 74.

ASEAN. (1967). ASEAN Declaration, 8 August 1967. Available. Online. http://www.aseansec.org/1212.htm (accessed on 21 July 2012).

ASEAN. (2004). ASEAN Declaration Against Trafficking in Persons, Particularly Women and Children. 29 November 2004. Available. Online.http://www.aseansec.org/16793.htm (accessed on 25 July 2012).

ASEAN. (2005). Chairman's Statement 'One Vision, One Identity, One Community'. 11 ${ }^{\text {th }}$ ASEAN Summit Kuala Lumpur. Available. Online. http://www.aseanec.org/18039.htm (accessed on 30 July 2012).

ASEAN. (2005). Kuala Lumpur Declaration on the Establishment of the ASEAN Charter, Kuala Lumpur, 12 December 2005. Available. Online. http://www.asean.org/18030.htm (accessed on 2 June 2012).

ASEAN. (2005). Terms of Reference of the Eminent Persons Group (EPG) on the ASEAN Charter, 12 December 2005. Available. Online. http://www.asean.org/18060.htm (accessed on 5 June 2012).

ASEAN. (2006). Report of the Eminent Persons Group on the ASEAN Charter, December 2006. Available. Online. http:// www.aseansec.org (accessed on 10 June 2012).

ASEAN. (2007). Chairman's Statement 'One ASEAN at the Heart of Dynamic Asia'. 13 ${ }^{\text {th }}$ ASEAN Summit Singapore. Available. Online. http://www.aseanec.org/121093.htm (accessed on 31 July 2012). 
ASEAN. (2007). The Charter of the Association of Southeast Asian Nation, December 2007. Available. Online. http://www. aseansec.org/21069.pdf (accessed on 15 July 2012).

ASEAN Secretariat. Interviewed by: Abdul Razak. (9 December 2010).

Burton, J., \& Landingin, R. (2007). Rifts over Charter for ASEAN May Hit Regional Integration. Financial Times, 31 July 2007. Available. Online. http://www.ft.com/cms/s/0/6e7570ae-3efe11dc-bfcf-0000779fd2ac.html\#axzz1d7D48aKE (accessed on 5 July 2012).

Collier, J., \& Lowe, V. (1999). The Settlement of Dispute in International Law. London: OUP.

Desierto, D.A. (2010). ASEAN's Constitutional of International Law: Challenges to Evolution under the New ASEAN Charter. Columbia Journal of Transnational Law, 49: 268.

Duxbury, A. (2007). Moving Towards or Turning Away From Institutions? The Future of International Organisation in Asia and the Pacific. Singapore Year Book of International Law, 11: 177.

Leviter, L. (2010). The ASEAN Charter: ASEAN Failure or Member Failure? New York University Journal of International Law and Politics, 43: 159.

Seah, D. (2009). The ASEAN Charter. International and Comparative Law Quarterly, 58: 197.

Thio, L. (1992). Implementing Human Rights in ASEAN Countries: Promises to Keep and Miles to Go Before I Sleep. Yale Human Rights and Development Law Journal, 2: 2 